Volume: 11 Issue: 2 Year: 2014

\section{The effects of poverty on mental health}

\section{Yoksulluğun ruh sağlığ1 üzerine etkileri}

\author{
Gülay Taşdemir ${ }^{1}$
}

\begin{abstract}
Poverty is a social problem which exists since the beginning of human history and it became a more severe problem after the industrial revolution. Although this concept exists since people started living together, it creates important macro factors such as the slowdown in economic growth in recent years, societies being driven by the market, and as well as macro indicators like increasing unemployment, domestic violence, increase in divorce rates and suicide rates. Reducing poverty is a situation which decreases human energy, prevents human life, and creating feelings like helplessness and loss of control of your life situation. If we consider the individual as a biopsychosocial entity, poverty has a negative impact on mental health. After World War II, the increase in mental disorders helped people to uncover the relationship between environment, socio-economic status and disease which were examined in studies made in the post-war environment. The purpose of this paper is to review the negative impact of poverty on mental health. Negative impact of poverty on the mental health has been demonstrated by many studies. Mental health professionals from different disciplines should be in collaboration to identify the mental health needs of poor people and to develop their coping skills may be the subject of research in this area.
\end{abstract}

\section{Özet}

Yoksulluk, insanlik tarihinden beri var olan, sanayi devrimi ile daha keskin hatlara bürünen sosyal bir sorundur. Bu kavram insanlarin birlikte yaşamaya başladığı günden bu yana varllğıın sürdürmesine rağmen, son yıllarda ekonomik büyümenin yavaşlaması, toplumların pazar tarafindan yönlendirilmesi gibi makro göstergelerin yanı sıra; bunlara bağlı olarak artan işsizlik, aile içi şiddet, boşanma oranlarındaki artış ve intiharlara kadar uzanan mikro düzeydeki bir süreci de beraberinde getirmektedir. Yoksulluk insan enerjini azaltan, insanca yaşamı engelleyen, bireyde yardımsızlık ve hayatının kontrolünü kaybetme duygusunu yaşatan bir durumdur. Bireyi biyopsikososyal bir varlık olarak düşünürsek yoksulluğun ruh sağllğı üzerine olumsuz etkileri olmaktadır. II. Dünya Savaşından sonra ruhsal bozukluklardaki artış, savaş sonrasında yapılan araştırmalarda çevre, sosyo-ekonomik durum ve hastalık arasındaki ilişkilerin ortaya çıkarılmasına neden olmuştur. Bu yazının amacı yoksulluğun ruh sağllğı üzerine olan olumsuz etkilerini gözden geçirmektir. Yoksulluğun ruh sağllğı üzerinde olumsuz birçok etki yaptığ1 yapılan araştırmalarla gösterilmiştir. Ruh sağlığ1 profesyoneli olarak farklı disiplinlerle işbirliği içinde yoksul insanların ruh sağlığını ve gereksinimlerini belirleme, onlarin baş etme becerilerini geliştirme bu alandaki araştırmaların konusu olabilir.

\footnotetext{
${ }^{1}$ Yrd. Doç. Dr., Pamukkale Üniversitesi Denizli Sağlık Yüksekokulu, gtasdemir@gmail.com
} 
Taşdemir, G. (2014). Yoksulluğun ruh sağllğ1 üzerine etkileri. International Journal of Human Sciences, 11(2), 74-88. doi: $\underline{10.14687 / \text { ijhs.v11i2.2681 }}$

Keywords: Poverty; mental health; psychiatric Anahtar Kelimeler: Yoksulluk; ruh sağllğ1; disorders

psikiyatrik bozukluklar

(Extended English abstract is at the end of this

document)

\section{Giriş}

Yoksulluk, insanlık tarihinden beri var olan, sanayi devrimi ile daha keskin hatlara bürünen sosyal bir sorundur (Küçükkaraca, 2001). Bu kavram insanların birlikte yaşamaya başladığı günden bu yana varlığını sürdürmesine rağmen, son yıllarda ekonomik büyümenin yavaşlaması, toplumların pazar tarafından yönlendirilmesi gibi makro göstergelerin yanı sıra; bunlara bağlı olarak artan işsizlik, aile içi şiddet, boşanma oranlarındaki artış ve intiharlara kadar uzanan mikro düzeydeki bir süreci de beraberinde getirmektedir (Oktik ve Sezer, 2004).

Birleşmiş Milletler Örgütünce dünyadaki en önemli 12 genel sorundan biri olarak yoksulluk kabul edilmiştir. Bu nedenle 1996 y1lı "Uluslararası Yoksulluğun Yok Edilmesi Yılı" olarak ilan edilmiştir. Uluslararası Hemşireler Birliği’nin de 2004 yllı teması,” Hemşireler Yoksulluğa Karşı, Yoksullarla El ele" dir (ICN on Poverty and Health, 2004). Ayrıca 2010 y1lında Avrupa Birliği y1lın temasını "Yoksulluk ve sosyal dışlanma ile mücadele" olarak ilan etmiş ve tüm üye ülkelerde yoksulluğa karşı etkinlikler, kampanyalar ve projeler düzenlenmesini planlamıştır (Dünya Yoksulluk ve Sosyal Dışlanma ile Mücadele Yıll, 2010).

Dünya Bankasına göre dünyada yaklaşık 1,5 milyar yoksul insan yaşamaktadır. Amerika'da yaklaşık 36 milyon kişi yoksuldur. Bunların \%39’u 6 yaş altı, \%20’si 18 yaş altı, \%10’u 65 yaş üstü insanlar oluşturmaktadır (Allender ve Spradley, 2001). Türkiye İstatistik Kurumu (TÜİK) tarafindan 2008 yılında hazırlanan “Tüketim Harcamaları, Yoksulluk ve Gelir Dağılımı” raporuna göre; 2006 yılında Türkiye nüfusunun \% 0.74 'ü açılk sınırının, \% 17.84’ü ise yoksulluk sınırının altında yaşamını sürdürmektedir (TÜİK, 2008). TÜİK’in 2009 y1lında uluslararası ölçütleri kullanarak yaptığ1 “Gelir ve Yaşam Koşulları Araştırması" sonuçlarına bakıldığında ise Türkiye'de yoksulluk oranı \%15.4’tür (10.5 milyon kişi) (Dünya Yoksulluk ve Sosyal Dışlanma ile Mücadele Yllı, 2010).

Bir ülkenin yoksullukla ilgili temel göstergelerinden biri gelir dağılımıdır. Ülkenin toplam gelirinin vatandaşlar arasında nasıl dağıldığına dair veriler yoksullukla mücadele için önemlidir. Boğaziçi Üniversitesi’nin 2010 yllında yaptığı bir çalısmadaki sonuçlara göre: 2008 yılında OECD (Organization for Economic Cooperation and Development) raporunda; 1980'lerden 1990'lara kadar en yüksek gelir grubunun gelirinin yükseldiği, en düşük gelir grubunun gelirinin en çok düştügü üçüncü OECD ülkesi olarak Türkiye olduğu bildirilmektedir. Aynı rapora göre 2000’li 
Taşdemir, G. (2014). Yoksulluğun ruh sağllğ1 üzerine etkileri. International Journal of Human Sciences, 11(2), 74-88. doi: $\underline{10.14687 / \text { ijhs.v11i2.2681 }}$

yılların ortalarında Türkiye 30 ülke arasında Meksika'dan sonra gelir dağılımının en eşitsiz olduğu ikinci ülke olmaktadır (Candaş ve ark., 2010).

Ruh sağlığ1, yaşamımızı sürdürürken nasıl düşündüğümüz, nasıl hissettiğimiz, kendimizi, yaşamımızı ve çevremizdeki insanları nasıl gördüğümüzle ilgilidir (Ar1, 2003). İnsanların yaşam kalitesini bozan ve yeti yitimine yol açan sağlık sorunlarının \%8.1'ini ruhsal sorunlar oluşturmaktadır. Bu durumun kalp hastalıklarında \%4.4 ve kanserde \%5.8 olduğu göz önüne alındığında ruhsal sorunların yıkıcı etkileri daha iyi anlaşılabilir. Ruhsal sorunları olan insanların büyük çoğunluğunun özellikle de sosyo-ekonomik düzeyi düşük kişilerde görüldüğü, bu kişilerin yardım aramadığı ya da arayamadığı ve tedavi edilemediği belirtilir (Candansayar ve Coşar, 2001).

Bireyi biyopsikososyal bir varlık olarak düşünürsek yoksulluğun ruh sağllğı üzerine olumsuz etkileri olabilmektedir. II. Dünya Savaşında ruhsal bozukluklardaki artış, savaş sonrasında yapılan araştırmalarda çevre, sosyo-ekonomik durum ve hastalık arasındaki ilişkilerin ortaya çıkarılmasına neden olmuştur (Oktik ve Sezer, 2004). Dünya Sağlık Örgütünün yapmış olduğu tanıma göre; sağlıklı olmak yalnızca hastalık veya sakatlığın olmayışı değil bedensel, ruhsal ve sosyal yönden tam bir iyilik halidir. Bu tanımdan yola çıkacak olursak; yoksul kişilerin sosyo-ekonomik yönden denge durumu yoktur. $\mathrm{Bu}$ da kişilerin sağlıklarını olumsuz yönde etkileyerek, onları sağlıksızlı̆ga götürecektir (Öz, 2004). Yoksulluk özellikle alt sosyo-ekonomik düzeyde yaşayan insanların hayatlarını önemli ölçüde etkileyerek onların yaşamdaki zorluklarla mücadele etme gücünü, psikolojik sağlıklarını olumsuz yönde etkilemektedir. Bu etki yoksul insanların kişilik özelliklerine ve davranışlarına farklı şekillerde yansımaktadır. Yoksul bireylerde; sigara-alkol kullanımı, anksiyete bozuklukları, depresyon, mental retardasyon, intihar, posttravmatik stres bozukluğu, aile içi şiddet, çocuk ve yaşlı istismarı, suça yönelmelerde artış daha sık görülmektedir (Allender ve Spradley, 2001). Yoksulluğun fiziksel hastalıklar ve bedensel yakınmaların yanı sıra kişilerde yoğun stres, içe kapanma, öz sayg1 yitimi, depresyon, anksiyete ve davranış bozuklukları gibi ruh sağllğı sorunlarına yol açabildiğini ortaya koyan çeşitli çalışmalar bulunmaktadır (WHO, 2000; Fryer ve Fagan, 2003; Kessler ve ark., 2005; Ulaş ve Kaya, 2009).

Bu yazıda yoksulluğun ruh sağlığı üzerine olan olumsuz etkileri gözden geçirilecektir.

\section{Yoksulluk Tanımı ve Nedenleri}

Dünya Bankasına göre yoksulluk, asgari yaşam standardına erişememe durumu, yani maddi nitelikteki olanaksızlıklar nedeniyle kaynaklara ve üretim faktörlerine ulaşamama ve asgari bir yaşam düzeyini sürdürecek gelirden yoksun olma durumudur (Küçükkaraca, 2001). TÜİK yoksulluğu mutlak yoksulluk ve göreli yoksulluk olmak üzere iki türlü tanımlamaktadır. Mutlak yoksulluk, bireylerin temel ihtiyaçlarını (giyecek, yiyecek, barınma) karşılayacak ekonomik düzeye sahip olmamaları, hane halkı veya bireyin yaşamını sürdürebilecek asgari refah düzeyini yakalayamaması 
Taşdemir, G. (2014). Yoksulluğun ruh sağllğ1 üzerine etkileri. International Journal of Human Sciences, 11(2), 74-88. doi: $\underline{10.14687 / \text { ijhs.v11i2.2681 }}$

durumudur. Göreli yoksulluk ise bireylerin, toplumun ortalama refah düzeyinin belli bir oranının altında olması ve toplumun genel düzeyine göre belli bir sınırın altında gelir ve harcamaya sahip olan birey veya hane halkının yoksulluğudur (TÜİK, 2013).

Yoksulluk nedenleri bireysel ve toplumsal olmak üzere ikiye ayrilmaktadır. Bireysel nedenler işsizlik, bireyin fiziksel sağlığının bozuk olması, fiziksel engellilik, ruhsal problemler, madde bağımlılı̆̆ı, geniş aileye sahip olma, düşük eğitim seviyesi, etnik ayrım, boşanma, eşin ölümü gibi nedenlerdir. Toplumsal nedenler ekonomik kriz, iş olanaklarının azlığ1 veya yokluğu, iş gücüne olan talebin azalması, göçlerle kentlerin hızlı olarak büyümesi sonucunda kalabalık ve düşük standartta yaşam süren nüfusta artış gibi nedenlerdir (Küçükkaraca, 2001; Turan ve Beşirli, 2008). Türkiye'de yoksulluğun önemli nedenlerinden birisi de gelir dağılımındaki adaletsizliktir. Milli gelirin çok büyük bir kısmı, toplam sayıları çok küçük olan bir nüfus grubunca paylaşılırken; küçük bir kısmı da, toplam sayıları oldukça büyük olan bir nüfus grubunca paylaşılmaktadır (İkizoğlu, 2001).

\section{Ruh Sağlı̆̆1 Tanımı ve Ruh Sağlığını Etkileyen Faktörler}

Ruh sağlığı ve ruhsal hastalıklar sıklıkla zor tanımlanır. İnsanlar toplumdaki rollerini yerine getirmede başarılı olduklarında, uyumlu davranışlar gösterebildiklerinde sağlıklı olarak görülür. Buna karşın rollerini, sorumluluklarını yerine getirmede başarısız, davranışları uygunsuzsa hasta olarak görülmektedirler. Yörükoğlu'na göre (1996), ruh sağllğı bireyin kendisi ve çevresiyle sürekli bir denge ve uyum içinde olmasıdır. Ancak bu denge ve uyum durağan bir nitelik taşımayıp, değişken bir denge ve esnek bir uyumdur (Yörükoğlu, 1996). Sigmund Freud'a göre, ruh sağllğ̆1 sevmek ve çalışmaktır (Öztürk, 2004).

Ruh sağlı̆̆ının belirleyici özellikleri kişinin yaşamının pek çok alanında bulunmaktadır. Bunlar; anlamlı bir iş, olumlu düşünce, yaşamdan zevk alma, mizah, uyku ve dinlenmeden yararlanma yeteneği, spontanlık, ilişkilerdeki memnuniyet, başkalarıyla ve ayrıca yalnız olarak çalışma yeteneği, eylemlerde sorumluluğu kabul etme ve duyguları ifade etme yeteneği gibi özelliklerdir. Kişinin tüm bunları yerine getirebilmesinde bazen sorunlar çıkabilmektedir. Ama genel olarak bunların hepsini ya da hepsine yakınını yerine getiren kişi, ruhsal yönden sağlıklıdır diyebiliriz. Kişinin yine bunları yerine getirebilmesi için uygun ortamda yetişmesi, uygun bir eğitimden geçmesi, ekonomik şartların yerinde olması gerekmektedir. Geçim sıkıntısı ve buna bağlı oluşabilecek stresler varsa, kişinin fizyolojik gereksinimlerini karşılamada sorun varsa bu durum bireyin Maslow'un temel insan gereksinimlerinin en üst düzeyinde bulunan kendini gerçekleştirememesine neden olacaktır. Bunun sonucunda da kişide ruhsal problemlerin oluşması muhtemeldir (Öz, 2004).

Ruh sağlığını etkileyebilecek faktörlere bakıldığında; kalıtsal özellikler, hamilelik süreci ve ortamı, psikonöroimmünojik durumlar, biyokimyasal ve hormonal etkenler, demografik özellikler, kültür, değerler ve inanç sistemleri, bilişsel yetiler, stresörler ve destek sistemleri, coğrafi durum, 
Taşdemir, G. (2014). Yoksulluğun ruh sağllğ1 üzerine etkileri. International Journal of Human Sciences, 11(2), 74-88. doi: $\underline{10.14687 / \text { ijhs.v11i2.2681 }}$

sağlık uygulamaları ve inançları, işsizlik, işten çıkarılma, sosyal güvenlik sistemlerinin yetersizliği, iş yerinde cinsiyet ayrımı, çocuk işçiler sorunu, ruhsal sorunlar nedeniyle rapor alma ya da iş bırakma şeklinde oluşan iş gücü kayıpları ruh sağlığını etkileyebilecek faktörlerdir (Öz, 2004; Öztürk, 2004).

\section{Yoksulluk ve Ruh Sağlığı İle İlişkili Bazi Kavramlar}

\subsection{Kadin}

Dünya üzerinde yoksulluktan en çok etkilenen gruplardan biri kadınlardır. Tüm toplumlarda kadınlar daha az eğitim almakta, okuma yazma öğrenmeleri engellenmekte, yoksulluğa mahkûm kılınmakta, erkeklerle aynı işi yaptıkları halde daha az para kazanmaktadırlar. Kadına yönelik bu ekonomik haksızlık bireysel olduğu kadar, toplumsal olarak da sürdürülmektedir. Birleşmiş Milletler Kalkınma Programı “İnsani Gelişmişlik Raporu”nda Türkiye, toplumsal cinsiyet eşitliği açısından 115 ülke içinde 109. sırada yer almaktadır. Bu raporda, Türkiye'de kadınların kazandıkları gelirin erkeklerin kazandığının \%26'sı olduğu belirtilmektedir. Yoksulluk kadınların eğitim alması önünde de bir engel oluşturmaktadır. Eğitimsiz olan, sosyal güvencesi olmayan, sağlık sorunları bulunan, yeterli beslenemeyen, kendini geliştiremeyen bir kadının yoksullaşması olasıdır (Küçükkaraca, 2001). Dünyada 1.3 milyar insan yoksulluk sınırının altında yaşamakta ve bunların \%70'ini kadınlar oluşturmaktadır (Dünya Yoksulluk ve Sosyal Dışlanma ile Mücadele Y1l1, 2010).

Yoksul kadınların erkeklere göre daha fazla biyolojik ve psikososyal stres etkenlerine maruz kaldığı, iş olanaklarının azaldığı, eğitim düzeyinin düştüğü, eşleri tarafindan fiziksel olarak kötüye kullanıldıkları, toplumsal sorunlarla başa çıkmada ve rol çatışmalarının mağduru olduğu, yoksulluk ve hastalık deneyimlerinden erkeklere göre daha fazla etkilendiği vurgulanmaktadır (Dünya Yoksulluk ve Sosyal Dışlanma ile Mücadele Yıll, 2010). Meksika'da yoksul kırsal alanlarda yaşayan 20-70 yaş aralığındaki 5457 kadın üzerinde yapılan kesitsel araştırmada düşük gelir düzeyine sahip olan kadınlarda depresif belirti yaygınlığı yüksek bulunmuştur (Fleischer ve ark., 2007). Yine Hussain ve arkadaşları (2004) tarafindan Pakistan'da 125 kadın üzerinde yapılan bir araştırmada da sosyal yetersizlikler ve eğitim düzeyi düşüklügünün depresyon ile güçlü bir ilişkisinin bulunduğu belirtilmiştir.

\section{2. Çocuk}

UNISEF (United Nations International Children's Emergency Fund) tarafindan yayınlanan Dünya Çocuklarının Durumu 2001 raporuna göre, yoksul bir ailede en çok etkilenen, en çok zarar görenler; yaşama, gelişme ve büyüme hakları riske atılanlar, o ailenin en küçük üyeleridir. Günümüzde gelişmekte olan ülkelerde doğan her 10 çocuktan 4’ü yoksulluk içindeki bir dünyaya gelmektedir. Çocuk haklarının yaygın bir biçimde ihlali de temelde gene yoksulluktan kaynaklanmaktadır. Bir başka deyişle yoksulluk arttıkça, evde paylaşılan besinler azalır, bu durum en çok anneleri ve bebekleri çaresiz bırakır. UNISEF'e göre yoksulluk, çocukların hem bedenlerini 
Taşdemir, G. (2014). Yoksulluğun ruh sağllğ1 üzerine etkileri. International Journal of Human Sciences, 11(2), 74-88. doi: $\underline{10.14687 / \text { ijhs.v11i2.2681 }}$

hem de zihinlerini tahrip eder ve sonuçta yoksulluk daha sonraki kuşaklara geçerek bir kısır döngü oluşturur. Bu nedenle de yoksulluğun önlenmesine çocukluk çağında başlanmalıdır. Günümüzde gelişmekte olan ülkelerde yaşayan çocukların \%40’1 (yaklaşık 500 milyon çocuk), günde 1 doların altında bir gelire sahiptir ve yoksulluk milyonlarca çocuğun ölümüne yol açtığı gibi, daha fazla sayıda çocuğun okula gidememesine, hastalanmasına veya çocuk işçi olarak yaşamını sürdürmesine neden olmaktadır (Çocuk Hakları Sözleşmesinin 13. Ylında Yoksulluk ve Çocuklar Üzerine Etkileri, 2004).

Çocukluk döneminde gelişmeye devam eden beynin yoksullukla birlikte gelen kronik açlık, demir eksikliği, olumsuz çevre koşulları gibi faktörlerden etkilenebileceği belirtilmektedir. Uzun süreli demir eksikliği zihinsel gelişimi olumsuz etkiler ve çocukta hafif derecede zihinsel gerilik oluşturabilmektedir (Şen, 2004). Yoksul çocukların algılama fonksiyonlarında ve öğrenme kapasitelerinde azalma olduğu, bu çocukların testlerden düşük puan aldıkları ve okul başarılarının da düşük olduğu gözlenmektedir. Ayrıca dil gelişimi açısından da yoksul çocukların risk altında oldukları saptanmıştır. Araştırmalara göre zihinsel gelişim ve dil gelişimi için çocuğun fiziksel sağlluğ1 yanında, yaşanılan fiziksel ortamın, annenin çocukla ilişkisinin, çevresel uyaranların ve erken çocukluk dönemindeki bakımın etkili olduğu tespit edilmiştir (Şen, 2004; Dashiff, 2009).

Yoksul ailelerin çocuklarının, öz güven gelişimlerinin eksik olduğu ve bu çocukların iletişimde bulundukları arkadaşları ile aralarında ekonomik farklılıkların olması nedeniyle, benlik saygılarında azalma, mutsuzluk, anksiyete ve bağımlılık duygularının yaygın olduğu belirtilmektedir. Yine yoksul ailelerin çocuklarının, farklı sosyo-ekonomik statüdeki akran gruplarına özenme ve daha üst sosyo-ekonomik sınıfa yükselme çabaları da suça yönelme eğilimlerini arttırmaktadır. Ayrıca yoksulluğun getirdiği stres nedeniyle aile içinde çocuk istismarı ve ihmali yaşanabilmektedir (Mcleod ve Micheal, 1993; Özmen ve ark., 2008). Yapılan araştırmalarda, yoksulluk ve yoksulluğun getirdiği yaşam şekli ile çocuk suçluluğu arasında bir ilişki bulunduğu, ayrıca bu kişilerde daha yüksek oranda anksiyete ve antisosyal davranış görüldüğü belirtilmektedir Mcleod ve Micheal, 1993; Özmen ve ark., 2008; Tümkaya ve ark., 2010). Ayrıca yoksul ailelerin çocuklarında ve gençlerinde umutsuzluk, sosyo-psikolojik uyumsuzluk, sosyal beceri eksikliği, öfke, yıkıcılık, saldırgan olma ya da boyun eğici davranma, dikkat eksikliği, hiperaktivite, davranış bozuklukları, depresyon ve intiharların sık görüldüğü çalışmalarda saptanmıştır (Atar ve ark., 1994; Kellam ve ark., 1998; Patel ve ark., 1998; Samaan, 2000; Schwartz ve ark., 1999; Aber ve ark., 2003; Çocuk Hakları Sözleşmesinin 13. Yıllında Yoksulluk ve Çocuklar Üzerine Etkileri, 2004; Frojd ve ark., 2006; Rafferty ve ark., 2010).

\subsection{Yaşl1}

Tüm dünyada gelir dağılımı eşitsizliğinden en çok etkilenen gruplardan biri de yaşlılardır. Yoksul yaşlılar hayatlarını daha erken yaşlarda kaybetmekte, geliri ve emekli maaşı olanlar ise daha 
Taşdemir, G. (2014). Yoksulluğun ruh sağllğ1 üzerine etkileri. International Journal of Human Sciences, 11(2), 74-88. doi: $\underline{10.14687 / \text { ijhs.v11i2.2681 }}$

uzun süre hayatta kalmaktadırlar. Türkiye'de 66-75 yaş arasındaki yaşlıların genel gelir oranı toplumun genel gelir oranından düşüktür ve bu düşüş devam etmektedir (Dünya Yoksulluk ve Sosyal Dışlanma ile Mücadele Yı11, 2010).

Geçmişte ağılıklı olarak kentlerde, bu gün ise kırsal bölgelerde yaşlıların herhangi bir sosyal güvencelerinin olmaması onları aile içinde kalmaya ve geniş aile şeklinde yaşantıya yöneltiyordu. Yoksul olsalar bile bu gizli yoksulluk biçimindeydi. Fakat günümüzde sosyal güvencesi olan yaşlılarda aldıkları maaşı zorunlu ihtiyaçlarına bile yetiremeyecek durumdadırlar. Kırsal bölgelerde artık kendisi tarımla uğraşamayan yaşlılar ihtiyaçlarını satın alma yoluyla karşılamak zorundadırlar. $\mathrm{Bu}$ durum onların gizli olan yoksulluğunu açığa çıkarmaktadır. Kırsal alanda yaşayan yaşlılar kentlerde yaşayan yaşlılara göre daha yüksek yoksulluk oranına sahiptir (Canatan, 2004).

Yaşlılar gelirlerini arttırmak için çalışmak isteseler de başta genel sağlık durumları yetersizdir ve sahip oldukları beceriler gelişen teknoloji ile uyuşmadığından çalışmaları zordur. Bundan daha önemlisi de zaten nüfus içinde işsiz ve genç olan geniş bir kitle bulunmaktadır. Yoksul yaşlılarda beslenme yetersizlikleri, yaşam koşullarının kötü olması ve uyaran azlığı nedeniyle psikotik tablolar, demans, Alzheimer hastalı̆̆1, deliryum, psikotik depresyon, intihar düşünceleri ve girişimleri sık görülmektedir (Akdemir ve ark., 2001; Canatan, 2004; Wahlbeck ve Makinen, 2008).

\subsection{Kadercilik ve Öğrenilmiş Çaresizlik}

Her şey kötüye gitmiş olsa da günün birinde birden bire her şey düzelebilir. Olağanüstü, sihirli, metafizik ve mistik bir güç ortaya çıkacak ve duruma el koyacaktır. Dünyayı ve dünyevi olanı değersiz hale getiren bir felsefe kabul görmeye başlar. Yoksulluğu kader haline dönüştüren işte bu bakış açısıdır. Kanaatkarlık ve azla yetinme giderek bir yoksulluk kültürü oluşturur. Kişilerin bu olumsuz yaşam koşullarından kurtulmak için daha çok çalışmalarına, daha çok istemelerine, yaşamı kontrol altına alma isteğinin yeşermesine engel olan kadercilik kültürüdür. Birileri, bir yerde, bir şekilde gelip onları kurtaracaktır. Yaşamı anlamlı hale getiren umut çok önemliyken, hiçbir şey yapmadan dışarıdan gelecek güce bağlanan beklenti kaderciliktir. Bu durum insanları kısır bir döngüye sokar (Doğan, 2004).

İnsanın en temel özelliklerinden biri, çevresini kontrol edebileceği ve değiştirebileceği yolundaki inancıdır. Doğumdan itibaren hareketleriyle nesneleri, davranışlarıyla da yakın çevresindeki insanları manipüle edebileceğini öğrenen bebekte giderek bir kontrol inancı gelişir. Bu inanç zamanla farklı durumlara genellenerek bir kontrol beklentisinin ortaya çıkmasına yol açar. İnsanlar zaman zaman çevrelerini kontrol edebileceklerine ilişkin inançlarını kısa ya da uzun süreli olarak kaybedebilirler. Kısa süreli inanç kayıpları huzursuzluk, hoşnutsuzluk belirtilerini ortaya çıkartmakta ve kontrolü tekrar sağlayabilmek için aşırı bir çabanın görülmesine neden olmaktadır (Freedman ve ark., 1989). 
Taşdemir, G. (2014). Yoksulluğun ruh sağllğ1 üzerine etkileri. International Journal of Human Sciences, 11(2), 74-88. doi: $\underline{10.14687 / \text { ijhs.v11i2.2681 }}$

Kontrol inancının hangi nedenlerle kaybolduğu sorusu ortaya çıkmıştır. Bu soruyu cevaplamaya çalışan görüşlerden biri Abramson, Seligman ve Teasdale’in yükleme kuramından esinlenerek geliştirdikleri öğrenilmiş çaresizlik modelidir. Öğrenilmiş çaresizlik terimi, bir bireyin davranışlarıyla olumsuz bir sonucu kontrol edebileceği halde, bu sonucu kontrol etmek için gereken davranışları yapamadığı ya da davranışları öğrenmede yetersiz kaldığı durumlara işaret etmek için kullanılmaktadır. Öğrenilmiş Çaresizliğin teorisi daha sonra his ve duygu yokluğu olarak tanımlanan depresyonu açıklayan bir model için insan davranışlarını da içine alacak şekilde genişletilmiştir. Depresyondaki insanlar çaresizliği öğrendikleri için o hale geliyorlardı. Depresyondaki insanlar ne yaparlarsa yapsınlar boşuna olacağını öğrenmişlerdi. Depresif insanlar hayatları boyunca hiçbir şeyi kontrol edemediklerini öğrenmişlerdir (Cüceloğlu, 1997).

Özellikle sosyo-ekonomik düzeyi düşük toplumlarda kontrolün dişardan olduğunu öğrenme davranışı benimsenir. Gücün kendilerinde olduğunu fark etmezler. Onların yoksul ve mutsuz olması başkalarından kaynaklanmaktadır. Bu düşünce biçimi özellikle yoksul kişilerin içinde bulundukları durumla (barınma sorunu, beslenme, giyecek, yiyecek, içecek sorunu) baş etme ve onları duygusal olarak korumaları açısından olumludur. Fakat bu durum kişide var olduğu durumu gerçekçi algılamayı ve çözüm yollarını görmeyi engelliyorsa, hayata karşı umudu, çabayı, çalışmayı, kendine olan güveni sarsıyorsa oldukça yararsız bir durumdur (Cüceloğlu, 1997; Doğan, 2004).

\section{Yoksulluk ve Bazı Psikiyatrik Hastalıklar}

\subsection{Somatoform Bozukluklar (Konversiyon Bozukluğu)}

Genel olarak alt sosyo-ekonomik düzeydeki kişilerde somatoform bozuklukların daha fazla görüldüğ̈̈ ifade edilmektedir. Genelde bu bireyler farklı iletişim seçenekleri bulamadıklarından, kendilerini nasıl ifade edeceklerini bilemediklerinden dolayı bedenlerini kullanmaktadırlar. Bu sayede hem ruhsal hastalık etiketinden kurtulmuş olacak hem de bedensel yakınmalar iletişim işlevinin yanı sıra koruyucu bir hoşgörü ile karşılandıklarından, ikincil kazanç sağlayıcı bir niteliği de taşıyacaktır (Çelikel, 2006).

Somatoform bozukluklardan biri olan konversiyon bozukluğu, alt sosyo-ekonomik düzeydeki bireylerde daha sık görüldüğü fakat bununla ilgili kesin veri bulunmadığı belirtilmektedir. 19. yüzyılda çok daha yaygın olduğu; günümüzde ise görme kaybı, afoni ve paralizilerin nadir görüldüğü, daha çok kırsal kesimde yaşayanların, sosyo-ekonomik ve eğitim düzeyi düşük olanların etkilendiği tahmin edilmektedir. Kadınlarda erkeklerden 2-5 kat daha fazla görüldügü bildirilmektedir (Sağduyu ve ark., 1997). Araştırmalara göre kırsal kesimde yaşama, düşük sosyoekonomik koşullar, düşük eğitim düzeyi ve düşük zeka düzeyi konversiyon bozukluğu sıklığını arttıran risk etmenleri olarak saptanmıştır (Tasman ve ark., 1997; Bhatia ve Vaid, 2000; Uğuz ve Toros, 2003). 
Taşdemir, G. (2014). Yoksulluğun ruh sağllğ1 üzerine etkileri. International Journal of Human Sciences, 11(2), 74-88. doi: $\underline{10.14687 / \text { ijhs.v11i2.2681 }}$

\section{2. Şizofreni}

Şizofreni tüm toplumlarda ve tüm sosyo-ekonomik ortamda görülmektedir. Sosyoekonomik yönden düşüklük ya da düzensizlik gösteren kesimlerde daha sık görüldüğüne ilişkin bulgular vardır. Epidemiyolojik çalışmalar şizofreni gelişme riskinin en alt sosyo-ekonomik gruplarda yer alan kişilerde üst gruplara göre yaklaşık 8 kat fazla olduğunu göstermektedir. Bu risk orta sosyo-ekonomik gruplara göre iki misli fazladır. Şizofreni tanısı almış kişilerin yaklaşık olarak yarısı alt sosyo-ekonomik grupta yer almaktadır. Şizofrenide özellikle hastalığın başlamasından 10 yıl sonra, alt sosyo-ekonomik sinıflardaki hastalar diğer hastalara göre daha kötü durumdadır. Şizofreninin yoksullukla ilişkisi bağlamında ele alınması görüşü, düşük sosyo-ekonomik duruma eşlik eden her değişkenin şizofreni tanısı almış kişilerde bulunduğu gerçeğiyle desteklenmektedir. Örneğin, işsizlik, girişim eksikliği, toplumsal yabancılaşma gibi etkenlerin yanı sıra evlenmemiş olma, madde kötüye kullanımı, şiddet ve azınlık olma durumu toplumdaki yoksul kişilerin ortak özellikleridir. Bu özelliklerin hastalıktan ortaya çıktığını varsaymaktan çok etiyolojideki rolünün daha dikkatli bir şekilde ele alınması zorunludur (Holzer ve ark., 1986). Düşük sosyo-kültürel düzeydeki toplum kesiminde daha çok stres ve yoksunluk etkenleri mi bu oranı yükseltmektedir? Yoksa ağır ruhsal bozukluk nedeni ile bu tür hastalar düşük sosyo-ekonomik kesimlere mi kaymaktadırlar? $\mathrm{Bu}$ soruların kesin yanıtı verilmemişse de ruh sağlığı ile yoksulluk arasında ilişki olduğu ve birbirlerini olumsuz etkilediği düşünülmektedir (Öztürk, 2004). Dohrenwend ve ark. (1992) göre düşük sosyoekonomik durum şizofreni sonucunda gelişir yani bir sonuçtur. Şizofreni tanısı almış hastalarda hiç ruhsal hastalığı olmayanlara göre kısmen çalışma ya da işsiz olma oranı 4.5 kat fazladır (Aro ve ark., 1995). Hastaların \%5-8'inin evsiz olduğu tahmin edilmektedir. Şizofreni tanısı almış kişilerin çoğu standartların altındaki evlerde yaşamaktadır. Düşük sosyo-ekonomik durumla ilişkili ölüm oranının normal nüfusa göre iki misli fazla olduğu tahmin edilmektedir (Allenbeck, 1989).

Ailenin sınıfsal konumunun düşük olması, annenin vitamin depolarının yetersizliği, gebelik sırasında geçirilen viral enfeksiyonlar, hipoksiye neden olan doğum travması ve göç etmiş bir ailenin çocuğu olarak dünyaya gelmek gibi değişkenlerde araştırmalarda sık olarak sorgulanmıştır ve şizofreni oluşumu ile ilişkisi gösterilmiştir. Ancak bu ilişkinin neden mi yoksa sonuç mu olduğu yönünde farklı görüşler bulunmaktadır. Yapılan çalışmalar yoksullukla ilişkili bu değişkenlerin şizofreniye neden olduğu yönünde kanıtlar sunmaktadır (Harvey ve ark., 1996; Dünya Yoksulluk ve Sosyal Dışlanma ile Mücadele Y111, 2010).

\subsection{Depresyon}

Duygularımızın fiziksel ve toplumsal çevre etkenleri ile ne denli etkilendiği herkesçe bilinir. Duygulanım bozukluklarında ruhsal-toplumsal etkenlerin yeri önemlidir. Önemli ekonomik 
Taşdemir, G. (2014). Yoksulluğun ruh sağllğ1 üzerine etkileri. International Journal of Human Sciences, 11(2), 74-88. doi: $\underline{10.14687 / \text { ijhs.v11i2.2681 }}$

sorunlar, aile bunalımları, yoksulluk, iş yaşamındaki çatışmalar ve işsizlik depresyonun ortaya ç1kmasında ve süreğenleşmesinde önemli rol oynar (Öztürk, 2004).

Duygudurum bozuklukları içinde özellikle major depresyon sosyo-ekonomik parametrelerle ilişkilidir. Günümüzde depresyon sıklığı giderek artmaktadır. Her 5 kadından biri her 7-8 erkekten biri yaşam boyu en az bir defa depresyon geçirmektedir. 2020 y1lında Dünya Sağllk Örgütüne göre dünyada en acil sağlık sorunları içinde ikinci sıraya yükselecek olan depresyon düşük sosyoekonomik sınıflarda daha yaygın görülmektedir (Dünya Yoksulluk ve Sosyal Dışlanma ile Mücadele Y1l, 2010). Birçok araştırmada düşük sosyal sınıfa ait bireylerde depresyonu da içeren ruhsal bozuklukların yaygınlığı, orta ve üst sınıflara göre daha yüksek bulunmuştur (Link ve ark., 1993; Wohlfarth, 1997; Almeida-Filho ve ark., 2004). Almeida-Filho ve ark. (2004) tarafindan Brezilya 'da yapılan bir araştırmada yoksul kent göçmenlerinde depresyonu da kapsayan ruhsal bozuklukların yaygınlığı yüksek bulunmuştur. Lorant ve ark. (2003)'nın yapmış olduğu bir başka çalışmada düşük sosyo-ekonomik düzeyde olan depresyon olguları sağlık hizmetlerinden de düşük oranda yararlandıkları saptanmıştır.

\section{Sonuç ve Değerlendirme}

Sonuç olarak, yoksulluğun ruh sağlığ1 üzerinde olumsuz bir çok etki yaptığ1 bazı araştırmalarla da görülmektedir. Yoksulluğun özellikle kadın, çocuk ve yaşlı üzerinde olumsuz etki yaptığı, bu kişilerde sosyo-psikolojik uyumsuzluk, sosyal beceri eksikliği, saldırgan olma ya da boyun eğici davranma, umutsuzluk, içe kapanma, özsayg1 yitimi gibi psikososyal sorunların; depresyon, somatoform bozukluklar ve şizofreni gibi psikiyatrik hastalıkların daha yaygın olduğu görülmektedir. Bu nedenle yoksulluk sorununun çözümünde kısa süreli ve geçici önlemler yerine, kalıcı ve makro çözümler getirilmelidir. Özellikle yoksullara eğitim, sağllk ve sosyal güvenlik hizmetlerinin götürülmesine yönelik çabaların artırılması ve yeni iş olanaklarının yaratılmasına çalışılmalıdır. Özellikle kadınların ve yaşlıların ekonomik alanda güçlendirilmesi gerekmektedir. Sosyo-ekonomik düzeyi düşük yaşlılara yönelik sosyal destek programlarının oluşturulması (yaşlı gündüz merkezleri gibi) önemli gereksinimlerden biridir. Ruh sağlığı profesyonelleri olarak yoksul insanların ruh sağlığını belirlemeye yönelik araştırmalar yapılmalı; bu toplumdaki yeni evli çiftlere periyodik düzende aile planlaması hakkında bilgi verilmeli; yeni çocuğu olan ailelere ebeveyn rolü hakkında, bebek bakımı, çocuğun gelişimi ile ilgili danışmanlık, aile içi iletişim konusunda bilgilendirme yapılmalı; stres ve öfke yönetimi; kişiler arası iletişim becerileri; problem çözme teknikleri ile ilgili eğitimler verilmelidir. 
Taşdemir, G. (2014). Yoksulluğun ruh sağllğ1 üzerine etkileri. International Journal of Human Sciences, 11(2), 74-88. doi: $\underline{10.14687 / \text { ijhs.v11i2.2681 }}$

\section{Kaynaklar}

Aber, J.L., Brown, J.L. ve Jones, S.M. (2003). Developmental Trajectories Toward Violence in Middle Childhood: Course, Demographic Differences and Response to School-Based Intervention. Developmental Psychology, 39(2), 324-348.

Akdemir, A., Atasoy, N. ve Sağnak S. (2001). Yaşl1lıkta Depresyon. 3P Dergisi, 9(2), 263-270.

Allenbeck P. Schizophrenia: a life-shortening disease. Schizophr Bull 1989; 15, 81-89.

Allender, J.A. ve Spradley, B.W. (2001). Community Health Nursing: Concepts and Practice, First Ed, Lippincott Williams\&Wilkins.

Almeida-Filho, N., Lessa, I. ve Magalhaes, L. (2004). Social Inequality and Depressive Disorders in Bahia, Brazil: Interactions of Gender, Ethnicity, and Social Class. Soc Sci Med, 59(7), 13391353.

Arı, F. (2003). Temel Sağhk Hizmetlerinde Calısan Hekim ve Hemşirelerin Rub Sağh̆̆ğ Sorunu Olan Bireye Karşı Tutumlar. Yayımlanmış Bilim Uzmanlığı Tezi, Hacettepe Üniversitesi Sağlık Bilimleri Enstitüsü, Ankara.

Aro, S., Aro, H. ve Keskimaki I. (1995). Socio-economic Mobility Among Patients with Schizophrenia or Major Affective Disorder. A 17-Year Retrospective Follow-Up. Br J Psychiatry, 166, 759-767.

Atar, B., Guerra, N. ve Tolan, P. (1994). Neighborhood Disadvantage, Stressful Life Events and Adjustment in Urban Elementary-School Children. Journal of Clinical Child Psychology, 23, 391400 .

Bhatia, M.S. ve Vaid, L. (2000). Hysterical Aphonia-an Analysis of 25 Cases. Indiann J Med Sci, 54(8), 335-338.

Canatan, A. (2004). Yoksulluk ve Yaşlılık. IV. Aile Şurası Aile ve Yoksulluk Bildirileri. Ankara, Türkiye, 18-20 Mayıs.

Candansayar, S. ve Coşar, B. (2001). Küreselleşme, Postmodernizm ve Kültürel Görelilik. Psikiyatride Biyomedikal Paradigma Nasil Korunur. Kriz Dergisi, 9(2), 41-47.

Candaş, A., Buğra, A., Yılmaz, V., Günseli, S. ve Yakut Çakar, B. (2010). Türkiye'de Eşitsizlikler: Kalıcı Eşitsizliklere Genel Bir Bakış. Boğaziçi Üniversites, İstanbul.

Cüceloğlu, D. (1997). İnsan ve Davranışı, Remzi Kitabevi, İstanbul.

Çelikel, F.Ç. (2006). Kent Yaşamının Bedenselleştirme Süreçlerine Katkıları. Kent ve Sağlık Sempozyumu. Bursa, Türkiye, 7-9 Haziran.

Çocuk Hakları Sözleşmesinin 13. Yıllnda Yoksulluk ve Çocuklar Üzerine Etkileri. Erişim: 01.08.2013,http://www.manevisosyalhizmet.com/wpcontent/uploads/2010/04/yoksulluk _ve_cocuklar.pdf.

Dashiff, C., Dimicco, W., Myers, B. ve Sheppard, K. (2009). Poverty and Adolescent Mental Health. Journal of Child and Adolescent Psychiatric Nursing, 22(1), 23-32.

Doğan, İ. (2004). Türkiye Yoksulluğunun Sosyo-kültürel Zemini. IV. Aile Şurası Aile ve Yoksulluk Bildirileri. Ankara, Türkiye,18-20 Mayıs.

Dohrenwed, B.P., Levav, I., Schorout, PE., Schwartz, S., Naveh, G., Link B.G, Skodol, A.E. ve Stueve, A. (1992). Socioeconomic Status and Psychiatric Disorders: The CausationSelection Issue. Science, 255(5047), 946-952. 
Taşdemir, G. (2014). Yoksulluğun ruh sağllğ1 üzerine etkileri. International Journal of Human Sciences, 11(2), 74-88. doi: $\underline{10.14687 / \text { ijhs.v11i2.2681 }}$

Dünya yoksulluk ve sosyal dişlanma ile mücadele yll. Erişim: 09.07.2013, http://www.psikiyatri.org.tr/presses.aspxpress=301\&type=23, TPD Basin Bülteni 2010.

Fleischer, N.L., Fernald, L.C. ve Hubbard, A.E. (2007). Depressive Symptoms in Low-income Women in Rural Mexico. Epidemiology, 18(6), 678-685.

Freedman, J.L., Sears, D.O. ve Carlsmith, J.M. (1989). Sosyal Psikoloji, Ara Yayıncllık, İstanbul.

Frojd, S., Marttunen, M., Pelkonen, M., Vonder Pahlen, B.L. ve Kaltiala-Heino, R. (2006). Perceived Financial Difficulties and Maladjustment Outcomes in Adolescence. European Journal of Public Health, 15(5), 542-548.

Fryer, D. ve Fagan, R. (2003). Toward a Critical Community Psychological Perspective on Unemployment and Mental Health Research. Am J Community Psychol, 32(1-2), 89-96.

Harvey, C.A., Pantelis, C., Taylor, J., McCabe, P.J., Lefevre, K., Campbell, P.G. ve Hirsch, S.R. (1996). The Camden Schizophrenia Surveys. II. High Prevalance of Schizophrenia in an Inner London Borough and its Relation Ship to Sociodemographic Factors. Br J Psychiatry, 168(4), 418-426.

Holzer, CE, Shea BM, Swanson JW, Leaf PJ, Myers JK, George L., Weissman, M.M. ve Berdnarski, P. (1986). The increased risk for specific psychiatric disorders among persons of low socioeconomic status. Am J Soc Psychiatry, 6(4), 259-271.

Hussain, N., Gater, R., Tomenson, B. ve Creed F. (2004). Social Factors Associated with Chronic Depression Among a Population-Based Sample of Women in Rural Pakistan. Soc Psychiatry Psychiatr Epidemiol, 39, 618-624.

ICN on Poverty and Health: Breaking the Link. Erişim: 01.08.2013 http://www.ordemenfermeiros.pt/relacoesinternacionais/gri_documentacao/ICN_FolhasI nformativas_vsingept/fl_versao_Ing/Human_Rights/5g_Fs-Poverty_Health.pdf.

İkizoğlu, M. (2001). Türkiye'de Yoksulluk ve Sosyal Yardim Uygulamalarmm Bu Günkü Durumu: İnsani Gelisme ve Sosyal Hizmet. Hacettepe Üniversitesi Sosyal Hizmetler Yüksekokulu, Ankara.

Kellam, S.G., Ling, X., Merisca, R., Brown, C.H. ve Lalongo, N. (1998). The Effect of the Level of Aggression in the First Grade Classroom on the Course and Malleability of Aggressive Behavior into Middle School. Development and Psychopathology, 10(2), 165-185.

Kessler, R.C., Chiu, W.T., Demler, Q. ve Walters, E.E. (2005). Prevalence, Severity And Comorbidity Of 12 Month DSM-IV Disorders In The National Comorbidity Survey Replication. Archives of general psychiatry, 62(6), 617-627.

Küçükkaraca, N. (2001). Yoksulluk ve Kadın, İnsani Gelişme ve Sosyal Hizmet, Hacettepe Üniversitesi Sosyal Hizmetler Yüksekokulu, Ankara.

Link, B.G., Lennon, M.C. ve Dohrenwend, B.P. (1993). Socioeconomic Status and Depression: The Role of Occupations Involving Direction,Control, and Planning. American Journal of Sociology, 98, 1351-13 87.

Lorant,V., Kampfl, D., Seghers, A., Delieg,e D., Closan, MC. ve Ansseau, M. (2003). Socioeconomic Differences in Psychiatric in-Patient Care. Acta Psychiatr Scand, 107, 170-177.

Mcleod, J.D. ve Micheal, J.S. (1993). Poverty, Parenting and Children's Mental Health. American Sociological Review, 58, 351-366.

Oktik, N. ve Sezer, S. (2004). Aile Içinde Intiharların Yoksullukla Ilişkisi: Muğla Örneği. IV. Aile Şurası Aile ve Yoksulluk Bildirileri. Ankara, Türkiye, 18-20 Mayıs.

Öz, F. (2004). Sağlık Alanında Temel Kavramlar, İmaj İç ve Dış Ticaret AŞ, Ankara. 
Taşdemir, G. (2014). Yoksulluğun ruh sağllğ1 üzerine etkileri. International Journal of Human Sciences, 11(2), 74-88. doi: $\underline{10.14687 / \text { ijhs.v11i2.2681 }}$

Özmen, D., Erbay Dündar, P. ve Çetinkaya, A.Ç. (2008). Lise Öğrencilerinde Umutsuzluk ve Umutsuzluk Düzeyini Etkileyen Etkenler. Anadolu Psikiyatri Dergisi, 9, 8-15.

Öztürk, O. (2004). Ruh Sağllğı ve Bozuklukları, 10. Basım, Nobel Tip Kitapevleri Ltd. Şti.

Patel, V., Pereira, J., Coutinho, L., Fernandes, R., Fernandes, J. ve Mann, A. (1998). Poverty, Psychological Disorder and Disability in Primary Care Attenders in Goa, India. $\mathrm{Br} J$ Psycbiatry, 172, 533-536.

Rafferty, Y., Griffin, K.W. ve Robokos D. (2010). Maternal Depression and Parental Distress Among Families in the Early Head Start Research and Evaluation Project: Risk Factors within the Family Setting. Infant mental health journal, 31(5), 543-569.

Sağduyu, A., Rezaki, M., Kaplan, İ., Özgen, G., Gürsoy Rezaki, B. (1997). Sağlık Ocağına Başvuran Hastalarda Dissosiyatif (Konversiyon) Belirtiler. Türk Psikiyatri Dergisi, 8(3), 161-169.

Samaan, R. (2000). The Influence of Race, Ethnicity and Poverty on Mental Health of Children. J Health Care Poor Underserved, 11(1), 100-110.

Schwartz, D., McFadye-Ketchum, S., Dodge, K., Pettit, G. ve Bates, J. (1999). Early Behavior Problems as a Predictor of Later Peer Group Victimization: Moderators and Mediators in the Pathways of Social Risk. Journal of Abnormal Child Psychology, 27, 191-201.

Şen, B.R. (2004). Aile Yoksulluğunun Çocuklar Üzerine Etkileri. IV. Aile Şurası Aile ve Yoksulluk Bildirileri, Ankara, Türkiye, 18-20 Mayıs.

Tasman, A., Kay, J. ve Lieberman, J. (2008). Psychiatry, Wb Saunder Company, Philadelphia.

Turan, M.T. ve Beşirli, A. (2008). Kentleşme Sürecinin Ruh Sağllğı Üzerine Etkileri. Anadolu Psikiyatri Dergisi, 9, 238-243.

TÜİK. (2008). Tüketim Harcamaları Yoksulluk ve Gelir Dağılımı: Sorularla Resmi İstatistikler Dizisi-6, Ankara.

TÜİK. Haber bülteni yoksulluk çalışması. Erişim: 09.07.2013 http)//www. tuik. gov.tr 2011.

Tümkaya, S., Aybek, B. ve Çelik M. (2010). Yoksul Ailelerden Gelen Ergenlerde Psiko-sosyal Bir Olgu Olarak Umutsuzluk ve Boyun Eğici Davranışların Incelenmesi. Uluslararası İnsan Bilimleri Dergisi, 7(1), 970-984.

Uğuz, Ş. ve Toros, F. (2003). Konversiyon Bozukluğunda Sosyodemografik ve Klinik Özellikler. Türk Psikizyatri Dergisi, 14(1), 51-58.

Ulaş, H. ve Kaya, B. (2009). Ekonomik Krizin Ruh Sağlığına Etkileri ve Çözüm Önerileri. TPD Bülteni, 12(1), 59-62.

Wahlbeck, K. ve Makinen, M. (2008). Prevention of Depression and Suicide, Mental Health in Older People, Consensus Paper, Jane-Llopis E ve Gabilondo A (Eds), European Communities, Luxembourg, 3-21.

WHO. (2000). Cross-national Comparisons of the Prevalences and Correlates of Mental Disorders. Bulletin of the World Health organization, 78(4), 413-426.

Wohlfarth, T. (1997). Socioeconomic Inequality and Psychopathology: Are Socioeconomic Status and Social Class Interchangeable? Social Science \& Medicine, 45, 399-410.

Yörükoğlu, A. (1996). Çocuk Ruh Sağlığı, 20. basım, Özgür Yayınları, İstanbul. 
Taşdemir, G. (2014). Yoksulluğun ruh sağllğ1 üzerine etkileri. International Journal of Human Sciences, 11(2), 74-88. doi: $\underline{10.14687 / \text { ijhs.v11i2.2681 }}$

\section{Extended English Abstract}

Poverty is a social problem which exists since the beginning of human history and it became a more severe problem after the industrial revolution. Although this concept exists since people started living together, it creates important macro factors such as the slowdown in economic growth in recent years, societies being driven by the market, and as well as macro indicators like increasing unemployment, domestic violence, increase in divorce rates and suicide rates. Reducing poverty is a situation which decreases human energy, prevents human life, and creating feelings like helplessness and loss of control of your life situation.

Poverty was declared as the world's most important 12th overall problem by the United Nations. For this reason, the year 1996 was declared as "International Year of Elimination of Poverty". The theme of 2004 was declared by the Internation Association of Nurses as "Nurses Against Povert, hand in hand with the poor". Also, in 2010 the theme of the European Union was declared as "the fight against poverty and social exclusion" and plans were made to organize activities, campaigns and projects in all member countries.

About 1.5 billion poor people live in the world according to the World Bank. Approximately 36 million people in America are poor. 39\% of them are under the age of 6 , and $20 \%$ of them are under the age of $18,10 \%$ of them are over the age of 65 . According to the the "Consumption Expenditures, Poverty and Income Distribution" prepared by Turkey Statistical Institute (TSI) in 2008, in $20060.74 \%$ of Turkey's population was below the hunger line, 17.84\% of them was below the poverty line. According to the results of the "Income and Living Conditions Survey" prepared in accordance with the internation criteria and applied by TUIK in 2009 , the poverty rate in Turkey is $15.4 \%$ (10.5 million people).

One of the basic indicators of a country's poverty is income distribution. Data on the distribution of the total income of the country's citizens is essential for poverty reduction. According to the results of a study made in 2010 by Boğaziçi University, in 2008 OECD report showed that the income of the high-income group increased in the 1980s until the 1990s and the income of the lowest income group in Turkey was reported to be the third lowest among OECD countries. According to the same report, Turkey had the second worst income distribution after Mexico in the mid-2000s.

Mental health is about how we think, how we feel about ourselves, our lives and how we see the people around us. $8.1 \%$ of the problems distrupting quality of life of the people by causing health problems and disability are mental health problems. This situation can be better understood by considering the devastating effects of mental health problems as this ratio is $\% 4.4$ for heart disease and $\% 5.8$ for cancer. The vast majority of people with mental health problems are especially thepeople who have low socio-economic level and it is indicated that these individuals can not have sought help or be treated.

If we consider the individual as being a biopsychosocial entity, poverty may have negative effects on mental health. The increase in mental disorders in World War II and the research in the post-war environment, helped us to uncover the relationship between socio-economic status and disease. According to the definition made by the World Health Organization, being healthy is not only the absence of disease or infirmity, it is a completed state of physical, mental and social well-being. If we go by this definition, there is no equilibrium state of the poor socio-economic aspects. This in turn adversely affect the health of people, take them unhealthy. The lives of people living in poverty, especially in the lower socio-economic level, are under a significant effect on the power to tackle the challenges in their life, their psychological health is affected negatively. This effect is reflected in poor people's personality traits and behaviors in different ways. Poor individuals have a higher rate of non-alcohol abuse, anxiety disorders, depression, mental retardation, suicide, post-traumatic stress disorder, domestic violence, child and elder abuse and overall crime. Several studies have proven that poverty can cause physical illnesses and 
Taşdemir, G. (2014). Yoksulluğun ruh sağllğ1 üzerine etkileri. International Journal of Human Sciences, 11(2), 74-88. doi: $\underline{10.14687 / \text { ijhs.v11i2.2681 }}$

physical symptoms, as well as mental problems like intense stress, social isolation, loss of selfesteem, depression, anxiety and behavioral disorders.

In conclusion, several studies show the negative impact of poverty on the mental health. Poverty, has a negative impact on especially women, children and the elderly with a negative impact on the socio-psychological maladjustment people, lack of social skills, being aggressive or submissive act, hopelessness, social isolation and psychosocial problems, such as loss of selfesteem, depression, somatoform disorders such as schizophrenia and psychiatric seems to be more common diseases. Therefore, solving the problem of poverty, rather than short-term and temporary measures, should be permanent and macro solutions. Especially the education, health and social security services should be given to the poor with increased efforts and the creation of new job opportunities is needed. In particular, women and the elderly should be strengthened in the economic field. Low socio-economic level of the creation of social support programs for the elderly (such as the elderly day centers) is one of the important requirements. Research should be done by mental health professionals to determine the mental health of the poor people, newly married couples in this society should be periodically informed about family planning layout and education should be given to the couples with young children about the new role of parenting with children and baby care, advice and training should be given on the development of the child within the family especially in the aspect of communication; stress and anger management, interpersonal and communication skills and problem-solving techniques. 